\title{
МОДЕЛЬ ФОРМУВАННЯ СТРАТЕГІЙ ІНШОМОВНОГО ПРОФЕСІЙНО ОРІЕНТОВАНОГО СПІЛКУВАННЯ МАЙБУТНІХ ПРОГРАМІСТІВ
}

Статтю присвячено розробизі й обьрунтуванню моделі формування стратегій іншомовного професійно орієнтованого спілкування майбутніх програмістів на основі соиіокогнітивного підходу. 3 изією метою, а також з метою відображення комплексного процесу формування означених стратегій використано метод моделювання, щзо дає можливість інтегрувати теоретичні та практичні аспекти іншомовної підготовки зазначених майбутніх фахівців. Здійснено схематичну побудову згадуваної моделі, в якій відображено їі структурні компоненти, принцципи їх функціонування $і$ внутрішні зв'язки. Конструювання моделі відбувалось із урахуванням принцципу системності, щзо передбачае цุілісність (характеризує сконструйовану модель як завершену конструкцію), наступність (втілюеться у поетапному поступальному русі вперед до визначеної мети навчання), структурованість (виявляється у багаторівневості, ієрархічності компонентів системи, логічному встановленні взаємозв'язків між ними та функціональність (виявляеться у виконанні функцій усіма компонентами і субкомпонентами моделі, реалізацї взаємозв'язків між ними). У науковій розвідиі викладено ключові характеристики моделі: гносеологічна, загальнометодологічна і психологічна; виділено ї̈ основні компоненти: иільовий (окреслюе мету $і$ завдання), концептуальний (відображае засади соціокогнітивного підходу), змістовий (реалізуеться в інтеграццї̈ його предметного та процесуального компонентів), процесуальний (визначає етапи та підетапи формування стратегій іншомовного професійно орієнтованого спілкування), результативний (передбачае досягнення відповідного рівня сформованості стратегій), коригувальний (дозволяе встановити зворотній зв'язок між усіма компонентами сконструйованої моделі та усунення виявлених недоліків). Автором запропоновано предмет подальших наукових розвідок.

Ключові слова: модель, стратегії іншомовного професійно орієнтованого спілкування, майбутні програмісти, комунікативні изілі, соціокогнітивний підхід, компоненти, критерії оцінтовання, рівні сформованості.

Постановка проблеми. Зміст навчання іноземної мови за професійним напрямом майбутніх програмістів у вищих навчальних закладах передбачає формування у студентів стратегій іншомовного професійно орієнтованого спілкування (СІПОС). Вибір суб'єктом мовлення тієї чи іншої комунікативної стратегії залежить від специфіки конкретної комунікативної ситуації і спрямований на досягнення конкретних комунікативних цілей. Ефективність формування СІПОС майбутніх програмістів виявдяеться під час іï моделювання та апробації у навчальному процесі шляхом проведення комплексного методичного експерименту. 3 метою цілісного відображення комплексного процесу формування СІПОС майбутніх програмістів вважаємо доцільним застосування методу моделювання, що дасть мождивість інтегрувати теоретичні і практичні аспекти іншомовної підготовки згаданих фахівців у ВНЗ, спрямованої на формування у них СІПОС. Зміст пропонованої наукової розвідки присвячено розробці моделі формування СІПОС майбутніх програмістів із використанням інтернету на основі соціокогнітивного підходу.

Аналіз досліджень. Аналізу сутності іншомовної комунікативної компетентності, що є контекстом формування іншомовних комунікативних стратегій, присвячено праці

“(C) Семеряк I. 3.

us 201 
I. Зимньої, М. Канале, С. Савіньйон та ін. Обгрунтуванню теоретичних засад змісту навчання іноземних мов присвячено праці О. Бігич, Н. Бориско, І. Задорожної, С. Ніколаєвої, Р. Мартинової, В. Плахотника, Г. Рогової та ін. Зміст навчання іноземної мови професійного спілкування досліджено у працях $\Lambda$. Зєні, М. Кокор, Н. Микитенко, Н. Рубель, О. Тинкалюк та ін. Визначення сутності, класифікація, формування і реалізація комунікативних стратегій (КС) стали предметом розвідок Ф. Бацевича, А. Белової, О. Винник, Г. Грайс, Т. ван Дейк, О. Іссерс, О. Ковригіної, І. Мельник, А. Морської, О. Семенюк, Д. Терещук та інших учених.

Науковці у своїх дослідженнях розгдядають стратегію як усвідомлення ситуації загалом, визначення напряму розвитку й організації впливу в інтересах досягнення цілей [2, с. 377-380].

Упродовж останніх років учені наголошувади на ефективності соціокогнітивного підходу до навчання іноземних мов [9; 11]. Врахування засад цього підходу є сьогодні особливо важливим і актуальним у зв'язку з необхідністю вдосконалення навчання іноземних мов, спрямованого на формування у студентів КС і СІПОС,.

Зазначений підхід акцентуе на соціадьних і когнітивних чинниках, задіяних унавчанні іноземних мов, а також наголошуе на інтеграції соціальної й емоційної сфер навчання 3 когнітивною, враховуючи біологічні схидьності дюдського розумудо навчання іноземних мов відповідно 3 соціальним контекстом їх уживання [10, с. 167-171].

Упродовж останніх десятиліть навчання іноземних мов зазнає значних змін. Викладачі іноземних мов організовують свою навчальну роботу відповідно до соціального замовлення суспільства на якісну іншомовну підготовку майбутніх програмістів, які працюватимуть у міжнародних компаніях в Україні і за кордоном і володітимуть іноземною мовою професійного спілкування на достатньому рівні. Одним зі шляхів піднесення якості іншомовної підготовки майбутніх програмістів є розробка й обгрунтування ефективної методики навчання іноземної мови за професійним спрямуванням, скерованої на розвиток у цих фахівців стратегій іншомовного професійно орієнтованого спілкування (СІПОС).

3 метою цілісного відображення комплексного процесу формування СІПОС майбутніх програмістів ми розробили модель, яка дає мождивість інтегрувати теоретичні і практичні аспекти іншомовної підготовки зазначених фахівців у вищих навчальних закладах на основі аналізу моделей формування у студентів немовних спеціальностей таких конструктів, як «компетентність», «готовність», «культура», «стратегї», обгрунтованих у наукових розвідках вітчизняних i зарубіжних учених із урахуванням специфіки застосування соціокогнітивного підходу [3, с. 166190; 6, c. 110].

Мета статті - цілісне відображення комплексного процесу формування стратегій іншомовного професійно орієнтованого спілкування майбутніх програмістів у контексті соціокогнітивного підходу.

Викдад основного матеріалу. Виходячи з визначеної мети, завданням є побудувати модель формування стратегій іншомовного професійно орієнтованого спілкування майбутніх програмістів на основі соціокогнітивного підходу.

Для реалізації цього завдання використали принцип системності, який окреслює вимоги до побудови змісту навчання іноземної мови професійного спрямування, організації процесу формування іншомовної професійно орієнтованої комунікативної компетентності студентів (ІПОКК), суб'єктів навчального середовища, тобто викладача і студентів [3, с. 93] і передбачае цілісність, наступність, структурованість та функціональність.

Цілісність дозволяе характеризувати пропоновану модель як завершену конструкцію, елементами якої є визначені інваріантні компоненти. 
Наступність утілюється у поетапному поступальному русі вперед до визначеної мети навчання.

Структурованість виявдяеться у багаторівневості, ієрархічності компонентів системи, граничній чіткості будови субкомпонентів, догічному встановленні взаємозв' язків між ними.

Функціональність моделі забезпечуеться виконанням функцій усіма iii компонентами i субкомпонентами, реалізацією взаємозв'язків між ними з орієнтацією на системотвірний компонент - цільовий, що визначає практичну мету навчання.

Ключовими характеристиками моделі, за В. Міхеєвим, є:

- гносеологічна - відіграє роль проміжного об'єкта у процесі пізнання педагогічного явища;

- загадьнометододогічна - дозводяе оцінювати зв'язки і відношення між характеристиками стану елементів навчально-виховного процесу на різних рівнях їх опису і вивчення;

- психодогічна - дозволяе анадізувати й характеризувати різні сторони навчальної і педагогічної діяльності та виявляти на цій основі психолого-педагогічні закономірності [4, с. 8$]$.

Сконструйована модель представлена такими компонентами: цільовим, концептуальним, змістовим, процесуальним, результативним і коригувальним. Взаємодія цих компонентів забезпечує ефективне функціонування моделі й досягнення запланованого резудьтату.

Цільовий компонент сконструйованої моделі відображає практичну мету навчання іноземної мови та іноземної мови професійного спілкування майбутніх програмістів. У контексті нашого дослідження практичною метою навчання іноземної мови у ВНЗ є поетапне покомпонентне формування СІПОС майбутніх програмістів на основі соціокогнітивного підходу з використанням інтернету в контексті формування у них ІПОКК. Задля досягнення поставленої мети необхідно виконати низку завдань:

1) формувати у студентів базу організаційних і прагматичних дінгвістичних знань, соціолінгвістичних знань та предметних знань з урахуванням домінантних стилів їхнього навчання, особливостей відображення навчального матеріалу в довготривалій пам'яті й особливостей концентрації уваги;

2) розвивати у студентів рецептивні, репродуктивні і продуктивні навички з урахуванням домінантних стилів їхнього навчання, особливостей відображення навчального матеріалу в довготривалій пам'яті й особливостей концентрації уваги;

3) розвивати у студентів рецептивні та продуктивні уміння 3 урахуванням домінантних стилів їхнього навчання, особливостей відображення навчального матеріалу в довготривалій пам'яті й особливостей концентрації уваги.

Концептуальний компонент моделі формування СІПОС майбутніх програмістів відображає засади соціокогнітивного підходу до формування у цих фахівців згаданого конструкту з використанням інтернету, а також низки дидактичних і методичних принципів його реалізації.

Змістовий компонент сконструйованої моделі реалізується в інтеграції його предметного та процесуадьного компонентів, зокрема - відборі мовного і мовленнєвого матеріалу, системі вправ і завдань, спрямованій на формування СІПОС майбутніх програмістів.

Процесуальний компонент моделі формування СІПОС майбутніх програмістів вкдючає етапи та підетапи формування СІПОС із використанням інтернету; домінантні форми організації навчання: практичні заняття, самостійну робота студентів, участь в онлайн чат-навчанні; ефективні технології навчання іноземних мов; методи активного навчання; засоби навчання (у контексті нашого дослідження - інтернет-ресурси) та організаційні особливості реалізації системи вправ і завдань.

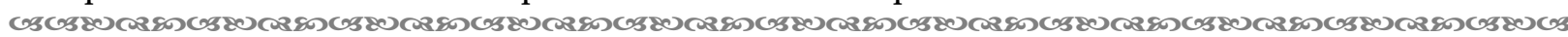
203 
Результативний компонент розробленої моделі прогнозує досягнення відповідного рівня сформованості СІПОС майбутніх програмістів. Моніторинг результативності навчання передбачає визначення рівнів сформованості комунікативної стратегії (КС) іСІПОС майбутніх програмістів, критеріїв оцінювання сформованості цих рівнів та показників їх сформованості.

Беручи за основу положення рівневого підходу до навчання іноземних мов, дотримуємося наукової позиції, що стандартизація рівнів сформованості стратегії іншомовного професійно орієнтованого спілкування майбутніх програмістів має відбуватися з урахуванням рівнів, визначених Загальноєвропейськими рекомендаціями 3 мовної освіти. Фахівці Ради Європи запропонували трирівневу шкалу рекомендованих рівнів володіння мовою, вважаючи, що запропоновані рівні покривають європейський навчальний простір відповідно до цілей осіб, які вивчають мови [1, с. 22-23]: А: інтродуктивний рівень (A1); середній рівень (А2). В: рубіжний рівень (B1); просунутий рівень (B2). С: автономний рівень (С1); рівень гдобального володіння (С2).

Кожен із рівнів, у свою чергу, поділяється на два підрівні, а також деталізується додатковим рівнем 3 позначкою «+», що означає більш поглиблений рівень [7, с. 13]. За своїми показниками додаткові рівні не мають виходити за межі показників рівнів [8, с. 57].

У контексті нашого дослідження приймаємо зазначені рівні як рівні сформованості стратегій іншомовного професійно орієнтованого спілкування майбутніх програмістів.

Шкала оцінювання рівня сформованості СІПОС майбутніх програмістів відповідно до вимог щодо оцінювання навчальних досягнень студентів, які діють у вітчизняних ВНЗ - 100-бальна (табл. 1).

Таблиия 1

\section{Шкала показників критеріїв сформованості стратегій іншомовного професійно} орієнтованого спілкування майбутніх програмістів

\begin{tabular}{|c|c|}
\hline Навчадьні досягнення студентів & $\begin{array}{c}\text { Показники критеріїв } \\
\text { у балах }\end{array}$ \\
\hline $\begin{array}{l}\text { демонструє відмінні результати відповідно до визначених } \\
\text { критеріїв у всіх видах мовленнєвої діяльності }\end{array}$ & $100 \div 90$ \\
\hline $\begin{array}{l}\text { демонструє дуже добрі результати відповідно до } \\
\text { визначених критеріїв та їх дескрипторів у всіх видах } \\
\text { мовленнєвої діяльності }\end{array}$ & $90 \div 81$ \\
\hline $\begin{array}{l}\text { демонструє добрі результати відповідно до визначених } \\
\text { критеріїв у всіх видах мовленнєвої діяльності }\end{array}$ & $80 \div 71$ \\
\hline $\begin{array}{l}\text { демонструє достатні результати відповідно до визначених } \\
\text { критеріїв у всіх видах мовленнєвої діядьності }\end{array}$ & $70 \div 61$ \\
\hline $\begin{array}{l}\text { демонструє задовільні результати відповідно до } \\
\text { визначених критеріїв у всіх видах мовленнєвої діяльності }\end{array}$ & $60 \div 51$ \\
\hline $\begin{array}{l}\text { демонструє незадовільні результати відповідно до } \\
\text { визначених критеріїв у всіх видах мовленнєвої діяльності }\end{array}$ & $50 \div 41$ \\
\hline не сформовані КС і СІПОС & $40 \div 0$ \\
\hline
\end{tabular}

На основі здійсненого аналізу можемо визначити наступні критерії оцінювання рівня сформованості КС і СІПОС майбутніх програмістів:

- адекватність вживання КС та СІПОС відповідно до комунікативної мети і рівня їх сформованості;

- гнучкість: гнучкий відбір і застосування КС і СІПОС, демонстрація умінь переформулювання висловлювання за допомогою різних дінгвістичних форм відповідно до ситуації, особи співрозмовника і т. д. 3 метою досягнення комунікативної мети;

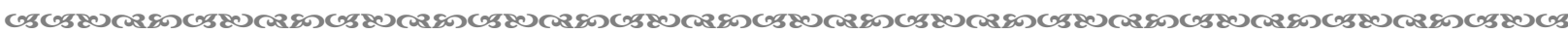
204 


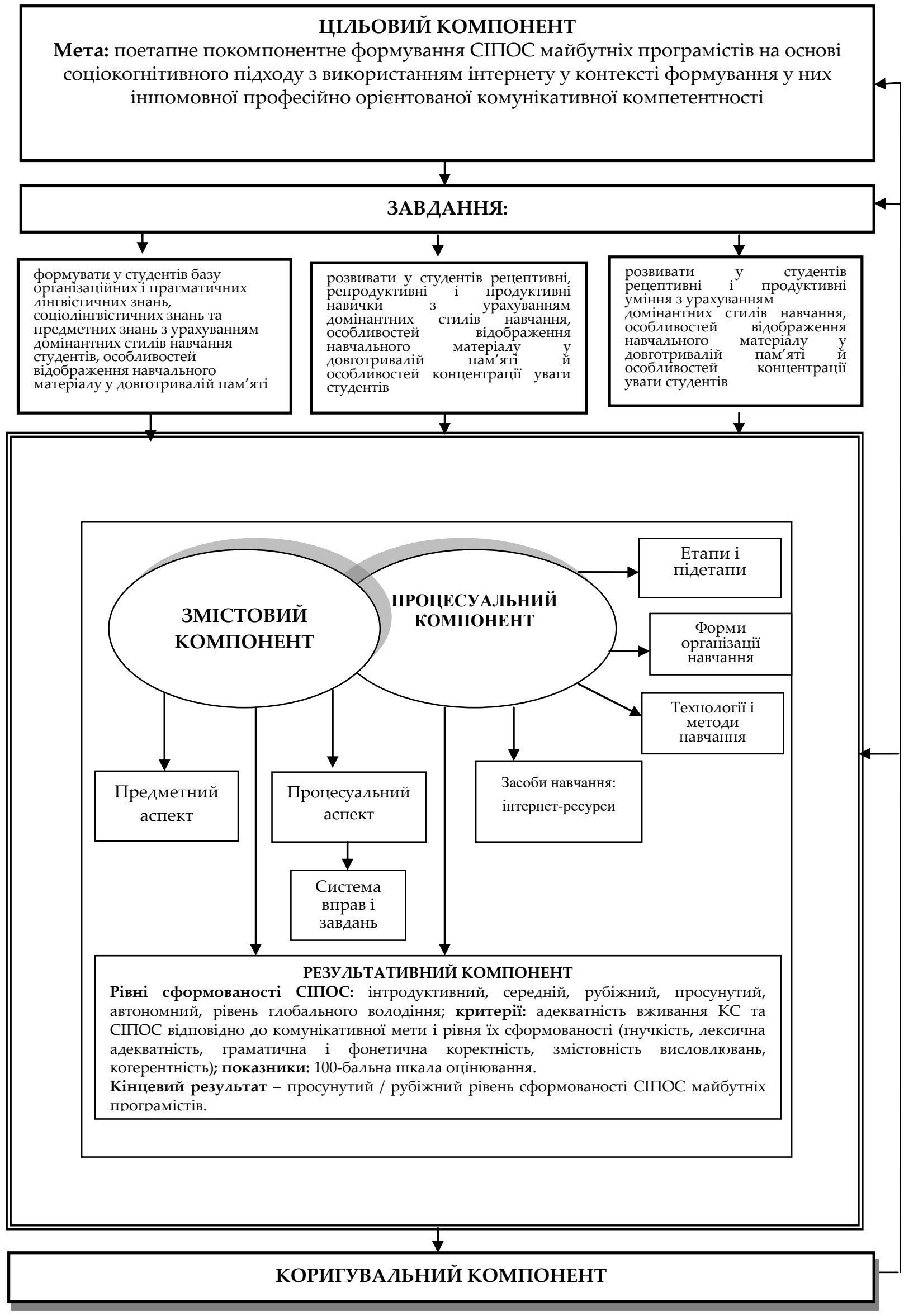

Рис. 1. Модель формування СІПОС майбутніх програмістів 
- лексична адекватність - використання лексики відповідно до комунікативного наміру та визначених КС і СІПОС у межах певного рівня їх сформованості;

- граматична i фонетична коректність: коректність вживання граматичних структур відповідно до комунікативного наміру і відібраних КС і СІПОС; дотримання правил орфографії, правильність вимови, відповідність інтонаційних моделей відповідним КС і СІПОС, темп мовлення;

- змістовність висловдювань: відповідність темі, розкриття теми, обгрунтованість відображення комунікативних намірів та форм їх реалізації;

- точність висловдювань: здатність передавати відтінки значень, використовуючи широкий діапазон кваліфікаційних мовних засобів, розставляти акценти відповідно до комунікативного наміру;

- когерентність: догічність викладу, чіткість структури, адекватний добір груп КС і СІПОС, зв' язність висловлювань, втілених у ряді КС і СІПОС - компонентів визначених груп КС і СІПОС, зреалізованість комунікативного наміру.

Ефективність процесу формування у студентів СІПОС оцінюється за результатами поточного та підсумкового контродю. Поточний контродь здійснюеться шляхом проведення поточного оцінювання: тестувань, написання і перевірки робіт, усної презентації творчих проектів, усного опитування і т.д. Підсумковий контродь проводиться під час модульного контролю, диференційованого заліку та іспиту.

Форми контролю ефективності процесу формування СІПОС майбутніх програмістів : усне опитування, презентації, перевірку письмових завдань, тестування, самоперевірку, взаємоперевірку, перевірку викладачем та груповий аналіз роздруків чатів, модульний контроль, диференційований залік, контрольна робота, іспит.

Коригувальний компонент сконструйованої моделі дозволяе встановити зворотній зв'язок між усіма іï компонентами, виявити необхідність втручання, спрямованого на усунення недоліків шляхом застосування коригувальних процедур, у компоненти чи субкомпоненти, які дають збій у процесі реалізації моделі і, відповідно, здійснити коригування елементів моделі на певних етапах і підетапах процесу формування СІПОС майбутніх програмістів. Сконструйована модель формування у майбутніх програмістів СІПОС з використанням інтернету у контексті соціокогнітивного підходу стала основою для розробки тематико-часової моделі навчального процесу [5, с. 407].

Висновки. Отже, сконструйована модель формування СІПОС майбутніх програмістів - це ієрархічна сукупність взаємопов'язаних субкомпонентів у межах інваріантних компонентів, які відображають складові цілеспрямованого педагогічного процесу: мети і завдань, концептуальної парадигми, змісту навчання (навчального матеріалу, конструктів, які формуємо у студентів, системи вправ і завдань) і організаційних особливостей (етапів навчання, форм організації навчання, технологій, методів, засобів навчання, очікуваного результату). Такими інваріантними компонентами моделі формування СІПОС майбутніх програмістів є: цільовий, концептуальний, змістовий, процесуальний, результативний та коригувальний.

На основі пропонованої моделі формування стратегій іншомовного професійно орієнтованого спілкування майбутніх програмістів у контексті соціокогнітивного підходу з використанням інтернету розроблено відповідну методику, яку впроваджено в навчальний процес ряду вишів України.

Предметом подальших наукових розвідок у цьому напрямку можуть бути особливості формування стратегій іншомовного професійно орієнтованого спілкування фахівців інших спеціальностей із перспективою розробки відповідних методик.

\section{Список використаних джерел:}

1. Загальноєвропейські Рекомендації з мовної освіти: вивчення, викладання, оцінювання / наук. ред. укр. вид. С. Ніколаєва. Київ : Денвіт, 2003. 273 с.

2. Мельник I. В. Типи КС. Studia Linguistica. 2011. Вип. 5. С. 377-380. 
3. Микитенко Н. О. Теорія і технології формування іншомовної професійної компетентності майбутніх фахівців природничого профілю: дис. ... д-ра. пед. наук: 13.00.04; 13.00.02. Тернопіль: Тернопільський національний педагогічний університет імені Володимира Гнатюка, 2012. 534 c.

4. Михеев В. И. Модедирование и методы теории измерений в педагогике : 3-е изд., стереотип. Москва : КомКнига, 2006. 200 с.

5. Семеряк I. 3. Соціокогнітивний підхід до формування стратегій іншомовного професійно орієнтованого спілкування майбутніх програмістів із використанням інтернету : дис. ... канд. пед. наук : 13.00.02. Тернопіль : Тернопільський національний педагогічний університет імені Володимира Гнатюка, 2016. 430 с.

6. Терещук В.Г. Формування англомовної лексичної компетентності студентів спеціальності «безпеки життєдіяльності» в умовах віртуального навчального середовища : дис. ... канд. пед. наук: 13.00.02. Тернопіль: Тернопільський національний педагогічний університет імені Вододимира Гнатюка, 2014. 330 с.

7. Черниш В. В. Теоретико-методичні засади формування у майбутніх учителів професійно орієнтованої англомовної компетентності в говорінні : автореф. дис. ... д-ра. пед. наук : 13.00.02. Київ : Київський національний лінгвістичний університет, 2015. 42 с.

8. Щукин А.Н. Обучение иностранным языкам : теория и практика : учеб. пособие для преподавателей и студентов. 2-е изд., испр. и доп. Москва : Филоматис, 2006. 480 с.

9. Atkinson, D. (Ed.). Alternative approaches to second language acquisition. London-New York : Routledge, 2011. $195 \mathrm{p}$.

10. Van Dijk, T. A., Wodak R., Meyer M. (Ed.) Critical Discourse Studies: A Sociocognitive Approach. Methods of Critical Discourse Analysis. Second ed. London : Sage, 2009. P. 1-33.

11. Stevik, E. Memory, Meaning and Method: A View of Language Teaching. 2nd ed. Heinle \& Heinle Publishers, 1996. 282 p.

\section{References:}

1. Nikolaieva, S. (Ed.) (2003). Zahalnoievropeiski Rekomendatsii z movnoi osvity: vyvchennia, vykladannia, otsiniuvannia [Common European Framework of Reference for Languages: Learning, Teaching, Assessment]. Kyiv: Lenvit [in Ukrainian].

2. Melnyk, I. V. (2011). Typy KS [Types of computer systems]. Studia Linguistica, 5, 377-380 [in Ukrainian].

3. Mykytenko, N. O. (2012). Teoriia i tekhnologii formuvannia inshomovnoi profesiinoi kompetentnosti maibutnikh fakhivtsiv pryrodnychogo profiliu [Theory and technologies of forming professional foreign language competence of prospective specialists of Sciences]. (Doctor's thesis). Volodymyr Hnatiuk Ternopil National Pedagogical University. Ternopil [in Ukrainian].

4. Mikheev, V. I. (2006). Modelirovanie $i$ metody teorii izmerenii $v$ pedagogike [Modeling and Methodology for the Theory of Measurements in Pedagogics]. Moscow [in Russian].

5. Semeriak, I. Z. (2016). Sotsiokognitivnii pidkhid do formuvania strategii inshomovnoiprofesino orientivanigi spilkuvania maibutnikh programistiv iz vykostaniam internety [A socio-cognitive approach to building strategies for communication on professional matters in a foreign language between future software programmers using Internet]. (Candidate's thesis). Volodymyr Hnatiuk Ternopil National Pedagogical University. Ternopil [in Ukrainian].

6. Tereshchuk, V. H. (2014). Formuvannia anglomovnoi leksychnoi kompetentnosti studentiv spetsialnosti "bezpeki zhittiediialnosti" $v$ umovakh virtualnogo navchalnogo seredovyshcha [Methodology of developing English Lexical Competence of future life safety specialists in virtual learning environment]. (Candidate's thesis). South Ukrainian National Pedagogical University named after K. D. Ushynsky. Odesa [in Ukrainian].

7. Chernysh, V. V. (2015). Teoretyko-metodychni zasady formuvania u maibutnikh uchiteliv profesino orientovanoi anglomovnoi kompetentnosti $v$ hovorini [Theoretical and methodological foundations future teachers' professionally oriented competence in English speaking formation]. (Extended abstract of Doctor's thesis). Kyiv National Linguistic University. Kyiv [in Ukrainian].

8. Shchukin, A. N. (2006). Obuchenie inostranym yazykam: teoriia i praktika: uchebnoe posobie [Teaching foreign languages: theory and practice: coursebook]. Moscow: Filomatis [in Russian].

9. Atkinson, D. (2011). Alternative approaches to second language acquisition. London - New York: Routledge [in English]. 
10. Van Dijk, T. A., Wodak, R., \& Meyer, M. (Ed.) (2009). Critical discourse studies: a sociocognitive approach. Methods of critical discourse analysis (pp. 1-33). London: Sage [in English].

11. Stevik, E. (1996). Memory, meaning and method: a view of language teaching. New York: Heinle and Heinle Publishers [in English].

Semeriak I. Z., orcid.org/0000-0001-8983-4551

\section{A DEFINED PATTERN USED TO SHAPE STRATEGIES FOR COMMUNICATION ON PROFESSIONAL MATTERS IN A FOREIGN LANGUAGE BETWEEN FUTURE SOFTWARE PROGRAMMERS}

The article aims to elaborate and justify a defined pattern to be used to shape strategies for communication on professional matters in a foreign language between future software programmers, based upon a socio-cognitive approach. To reflect the process of shaping these strategies, the author used a modelling principle integrating theoretical and practical aspects of training through elaboration of a layout for the said pattern wherein its structural elements are reflected, as well as principles of its functioning and the underlying links. This pattern was developed with a view to apply the Systemic Principle stipulating for integrity (defining the pattern as a finite structure), consistency plus structural build-up (embodied in the progressive motion towards the stipulated goal), and functionality (manifesting itself as all of the components and interrelations of the pattern fulfilling their respective functions, to the benefit of the ultimate outcome). The research stipulates key characteristics of the subject pattern, drawing on the realms of gnoseology, general methodology, and psychology. Principal components of the pattern were outlined, specifically those pertaining to target (defining the goal and the assignment); concept (reflecting foundations of the socio-cognitive approach); content (emerging as an integration of its subject component and its processual component); process (i.e., shaping the strategies for communication on professional matters in a foreign language, broken down, stage-by-stage); result (aiming at achievement of a certain level of strategies' maturity); and correction (allowing for a feedback from all of the pattern components and for elimination of defects, if any be detected). The author's idea merits further academic research in this area.

Key words: pattern, strategies for communication on professional matters in a foreign language, future software programmers, communication-related goals, socio-cognitive approach, components, evaluation criteria, levels of strategy maturity.

Дата надходження статті: 19.10.2020 p.

Рецензент: доктор педагогічних наук, професор Микитенко Н. О.

\section{МОНІТОРИНГОВЕ ДОСАІДЖЕННЯ РОЗВИТКУ ПРОФЕСІЙНОЇ УСПІШНОСТІ МАЙБУТНІХ УЧИТЕЛІВ}

У статті висвітлено результати моніторингу розвитку професійної успішності майбутніх учителів у педагогічних закладах вищої освіти. На основі проведено опитування серед студентів педагогічних спецііальностей, виокремлено чинники професійної успішності та уявлення щодо особистісних якостей та компетентностей, які забезпечать успінність професійної діяльності вчителя.

"(C) Скорик T. B.

030380 